\title{
EXPLORING EFL STUDENTS' DESCRIPTIVE PARAGRAPH WRITING ABILITY THROUGH CRITICAL ASSESSMENT PROCESS
}

\author{
Ida Bagus Nyoman Mantra*, Anak Agung Putu Arsana, I Gusti Ayu Putu Tuti Indrawati, \\ Anak Agung Rai Laksmi \\ Faculty of Teacher Training and Education, Mahasaraswati Denpasar University \\ bagusmantra@unmas.ac.id*
}

\begin{abstract}
Writing is a visual depiction of thoughts, feelings, and ideas using the written language for communication purposes or conveying certain messages. Having the ability to write, of course, allows humans to communicate ideas, appreciation, and experiences to others. Writing skill is possessed through intensive training and guidance which must be trained continuously to gain excellent writing skill. This study explores EFL learners' writing ability in actualizing their skill in writing a descriptive paragraph. The study revealed that EFL learners' writing ability is under expected skill. Therefore, this study implies that intensive improvement programs should be conducted by the educational institution to maximize learners' writing skills.
\end{abstract}

Keywords: Exploring, Learners, Descriptive, Paragraph, Writing

\section{Introduction}

Assessment is a series of activities to obtain, analyze, and interpret data about the process and learning outcomes of students which are carried out systematically and continuously, therefore it becomes meaningful information in decision making (Tzuriel, 2011). Learning assessment must be designed to be able to measure and provide information about the achievement of student competencies obtained through face-to-face activities, structured assignments, and unstructured independent activities. Various kinds of assessment techniques can be carried out complementary according to the competency being assessed (Widiastuti, et al, 2019).

It can be ascertained that every educator who carries out learning assesses the learning outcomes of their students (Leung, C. (2007). Assessing students' learning outcomes is an integral part of educators' duties. Every educator is obliged to assess the learning outcomes of their students (Widiastuti, et al, 2020). The assessment carried out by educators varies greatly in its implementation. Some educators deliberately prepare it well, others carry out the assessment just to fulfill the completeness of their teaching. For professional educators who view their 


\section{International Journal of Linguistics and Discourse Analytics}

Vol.2, No.2, March 2021

P-ISSN 2721-8899 E-ISSN 2721-8880

duties as special skills that are not owned by other professions, the results of the assessments carried out are actually a touchstone for their success as educators so that they are always used to improve their professionalism in teaching (Widiastuti, et al, 2020). Educators should always try to prepare, implement and review the results of the assessment as well as possible(Alavi, \& Taghizadeh,2014). This condition is thought to be not fully lived up to by educators at school so it is not surprising that teaching assignments tend to be routine in nature.

Language assessment should be conducted in line with the appropriate characteristics of classroom assessment to improve students' ability (Widiastuti, \& Saukah, 2017). In relation to the assessment of writing skills, Oshima and Hogue (2007:196) state that there are five indicators to measure students' writing ability such as format, punctuation and mechanics, content, organization, grammar, and sentence structure. However, the scoring criterion is not used appropriately in assessing students' writing ability by the teacher in the teaching-learning process. The teacher sometimes assesses the students by focusing only on two of five indicators; there are grammar and content from five indicators. Moreover, students do not understand clearly the criteria of the assessment that teacher uses to assess their writing ability. Thus, students do not know what they should do to get a good score in writing paragraphs during the teaching-learning process (Mantra, Widiastuti, 2019).

Writing is a productive activity to express ideas, thoughts, knowledge, and feelings. In writing activities, then the writer must be skilled at utilizing grammar, language structure, and vocabulary. It is a productive activity because writing activities produce a piece of writing, and is referred to as expressive activity due to writing activity is an activity that expresses the author's ideas, thoughts, feelings, and knowledge to readers (Wirastuti, \& Mantra, 2019).

Writing is very unique. It has unique aspects that are not common to other skills. It involves one's intense participation, engagement, even immersion in the process, both solitary and collaborative, both conscious and subconscious, and both physical and mental. In addition, writing is a lonely act because the audience is not physically present. Furthermore, the writer must possess a clear sense of cultural and technical writing expectation of English, so that there is no miscommunication of the intended message. Therefore, characteristics of good writing should be comprehensively understood to create a good piece of writing (Cheung, 2016).

Writing skills constitute complex capabilities, which are demanding a number of knowledge and skills. To write an essay that is even simple, technically demanded to meet the basic requirements as if we write intricate essays (Huda, Turahmat, \& Azizah, 2018). We must be able to develop ideas, present them in structured sentences and paragraphs logically. The complexity of writing can see from some factors: psychological, linguistic, and cognitive factors (Mantra, Widiastuti, 2019). If we see from the psychological factor, writing is a solitary act without an audience present. From the linguistic factor, writing must be constructed more carefully, concisely, and coherently to ensure the meaning is clear. Moreover, from cognitive 


\section{International Journal of Linguistics and Discourse Analytics}

Vol.2, No.2, March 2021

P-ISSN 2721-8899 E-ISSN 2721-8880

factors, writing is usually learned through formal instruction rather than through the natural acquisition process. In addition, it takes time for reading, thinking, talking, writing, and rewriting. Moreover, its process requires the writer to open his mind and to be willing to explore feelings and ideas.

Good writing is very important in conveying a message. Specific words are needed and combined to create sentences to convey ideas so that listener and reader will understand. Also, writing must be constructed more carefully, concisely, and coherently to ensure the meaning is clear (Awalludin, \& Lestari, 2017). Writing is effective if the message in it is easy to follow and to understand because of a good shape and a good organization. Specifically, in writing a paragraph, language learners must employ all paragraph criteria of writing a good paragraph to ensure the message is clear for the readers. A paragraph is a set of sentences that are connected in a series to form an idea. In paragraphs, these ideas become clear by descriptions that clearly present the point of view (Farhan, Martha, \& Putrayasa, 2019).

A paragraph is the essence of the pouring of the fruit thoughts in an essay. A paragraph contains a unit of thought which is supported by all the sentences in the paragraph, starting from the introductory sentence, main sentence or topic sentence, sentence explanatory until the closing sentence (Awalludin, 2018). The sentences set are deeply related to each other a series to form an idea. Paragraphs are part of the essay or part of speech. Where paragraphs are marked by unity ideas that are higher or broader than a sentence. Hence, paragraphs generally consist of a number of sentences. Sentences the each other related to express a certain idea.

Various research has been conducted to teach writing skills and only a few studies conducted to critically invigorate the language learners' writing ability to see the students' real ability in utilizing all criterion concerning good paragraph writing. Therefore, this study was considered to be important to be carried out to reveal the students' existing ability in employing their skills in writing.

\section{Methods}

In this present study, the researcher used an ex post facto research design with descriptive analysis. Ex post facto is taken from Latin for "after the fact," which indicates that ex post facto research is conducted after variation in the variable of interest has already been determined in the natural course of events. The statement shows that the ex post facto research is used to investigate to reveal the existing phenomena.

In this study, only 40 students were determined as the samples of the study. They were determined by means of random sampling technique with lottery system because this method was still regarded as the best method of drawing representative samples of homogeneous populations. The use of a random sampling method with a lottery system suggests that all populations have the same opportunity to be selected and included as the 


\section{International Journal of Linguistics and Discourse Analytics}

Vol.2, No.2, March 2021

P-ISSN 2721-8899 E-ISSN 2721-8880

samples of the study. The data of the present study were gathered by administering the research instrument in the form of a picture description.

The instrument was administered by the researchers and the samples were given 50 minutes to do the test. Moreover, students were given six topics then they had to choose one of them to compose their writing in six to twelve sentences which consisted of the generic structure (identification, description, and conclusion). The obtained data were analyzed by using a normreference measure of five standard values which respectively showed excellent, good, sufficient, insufficient, and poor achievement of a descriptive paragraph. The formula of norm-referenced measure of five standard values

\section{Findings and Discussion}

To measure the achievement of the descriptive paragraph writing ability of the students, the researchers provided the research instrument in the form of paragraph writing. The students in this study are currently studying for a teaching degree in English language teaching. Furthermore, the students had to choose one of six pictures given then write a descriptive paragraph based on the picture that had been already chosen. The paragraph should consist of 612 sentences, and it had to be finished in 30 minutes. Moreover, the descriptive paragraph had to fulfill five criteria of a good paragraph as what has already been stated in the instruction of the test.

Here is an ecample of students' writing: "Abbey is my lovey black cat. He walks with pride and elegance, performing a dance of disgust while slowly lifting and lowering each leg with the gentleness of a Balinese dancer. He spends most of outside hunting mice and insects. He enjoys stalking a eunning mouse around my yard. Abbey is as fussy about other people coming to my house and his foods. He only eats imported dry food and he doesn't want to befriends with other cats. He likes to be petted on his back. Abbey is always protecting his territory. He is a strong cat and very independent. He always protects my house from mice coming to inside my room. I love my cat because he is a nice and strong cat."

All the paragraphs were alyasis using scoring rubric to cosistantly analysed the students' paragraphs in terms of content, organization, vocabulary, grammar and mechanics. The results of the students' paragraphs were used as data to be computed in getting mean score (M) and standard deviation (SD). The results of the data analysis were analyzed by using normreferenced of five standard values clearly pointed out that $5.00 \%$ of the students in this study obtained excellent achievement of descriptive paragraph writing; $30.00 \%$ of the students attained good achievement; $32 \%$ of the students achieved sufficient achievement; $25.00 \%$ of samples got the insufficient achievement, and $8.00 \%$ of the students were in poor achievement. 
International Journal of Linguistics and Discourse Analytics

Vol.2, No.2, March 2021

P-ISSN 2721-8899 E-ISSN 2721-8880

Table 1. The Summary of the Finding

\begin{tabular}{|c|c|c|c|}
\hline No & Converted Scores & Percentage & Achievement Category \\
\hline 1 & $\geq 84.64(\mathrm{~A})$ & $5 \%$ & Excellent \\
\hline 2 & $\geq 62.91<84.64(\mathrm{~B})$ & $30 \%$ & Good \\
\hline 3 & $\geq 19.42<41.15(\mathrm{C})$ & $32 \%$ & Sufficient \\
\hline 4 & $\geq 19.42<41.1(\mathrm{D})$ & $25 \%$ & Insufficient \\
\hline 5 & $<19.42(\mathrm{E})$ & $8 \%$ & Poor \\
\hline & & $100 \%$ & \\
\hline
\end{tabular}

Based on the results of the analysis, the findings of this study showed that there were still many students had insufficient and poor ability in writing descriptive paragraph. The result of this study showed that in term of the format of the paragraph, there are some students were able to write a paragraph in the correct format. A number of the students had been able to place the title within the correct order and indented the primary sentence. Additionally, they gave a margin on each side in order that their paragraphs were tidy enough. However, many students in this study were failed to indent their initial sentence that was as an identity to begin a paragraph. Moreover, there were a number of the students failed to give margins in their paragraphs which made their paragraphs untidy. The untidy works were additionally caused by an excessive amount of corrections they made on their paragraphs. Thus, the readers hard to perceive the content of the students' descriptive paragraph.

Most students in this study were able to use capital letters and commas in their descriptive paragraphs properly. They additionally were able to write sentences with correct word spellings. An accurate orthography is terribly vital in writing as a result of it created the paragraph simply to know and it avoided ambiguity. However, in writing a descriptive paragraph, some students of the study still wrote misspelling words. It appeared that they failed to extremely keep in mind the orthography of English words.

Additionally, the study found some students were not ready to place lowercase letters and commas properly. Most of the students wrote paragraphs which were not matched the assignment. A number of the students failed to write coherent paragraphs, there was no transition signal in every sentence from the paragraph which connected the primary sentence to consequent sentences. Transition signal builds the sentences flow swimmingly and naturally to consequent sentence. Moreover, they unremarkably used sentences in constructing their paragraph. It created the paragraph becoming monotone, thus it couldn't show their literary genre.

A number of students were able to organize the paragraphs in which a number of the students of the study were able to write a paragraph with a transparent identification. Moreover, they were able to write a paragraph with a clear description and some students wrote their 


\section{International Journal of Linguistics and Discourse Analytics}

Vol.2, No.2, March 2021

P-ISSN 2721-8899 E-ISSN 2721-8880

descriptive paragraph with correct generic structure. However, some students had a downside in writing a conclusion. They forgot to finish their paragraph with a closing sentence. Although the conclusion within the descriptive paragraph was nonmandatory, it is, however, in this study students were asked to write down the conclusion by considering the outline as that they had to explain.

Based on the analysis, in terms of synchronic linguistics and structure, it had been found that some students wrote descriptive paragraphs with smart synchronic linguistics. they used sentences to make up their paragraph to construct understandable paragraphs. However, several students forgot to place suffix-s or -es behind the noun once the noun was plural. In conclusion, the results of this study showed that there was still a high percentage of the students who were unsuccessful in writing descriptive paragraphs. Therefore, intensive writing classes should be undergone by the students to improve their writing skills.

\section{Conclusion}

This study concluded that writing is important to form the students to do because writing help students to express something, their ideas, opinion, and feeling. Moreover, writing can help the student learn to organize and clarify various concepts and help to absorb and process information, and train to think actively. Thus, it is clear that writing is very useful, even though the writing process still seems difficult. This study found that many students cannot write topic sentences correctly and can not write sentences correctly to construct paragraphs. As a result, the ideas that they tried to describe were not organized well, consequently, the paragraphs that they constructed were not easy to understand. Therefore, this study suggests that teachers should intensify the writing practices in the classroom to make their students have higher writing skills

\section{References}

[1] Alavi, S. M., \& Taghizadeh, M. (2014). Dynamic assessment of writing: The impact of implicit/explicit mediations on L2 learners' internalization of writing skills and strategies. Educational Assessment, 19(1), 1-16.

[2] Awalludin, A. (2018). Efektivitas Model Decision Making dalam Pembelajaran Menulis Paragraf Persuasif Siswa Kelas X SMK Trisakti Baturaja. Jurnal Bindo Sastra, 2(1), 160. doi:10.32502/jbs.v2i1.923

[3] Awalludin, A., \& Lestari, Y. (2017). Pengembangan Modul Menulis Makalah pada Mata Kuliah Pengembangan Keterampilan Menulis. Jurnal Bindo Sastra, 1(2), 122. doi:10.32502/jbs.v1i2.762 
International Journal of Linguistics and Discourse Analytics

Vol.2, No.2, March 2021

P-ISSN 2721-8899 E-ISSN 2721-8880

[4] Cheung, Y. L. (2016). Teaching Writing. In W. A. Renandya, \& H. P. Widodo (Eds.), English Language Teaching Today: Building a Closer Link Between Theory and Practice. New York, NY: Springer International.

[5] Farhan, A., Martha, I. N., \& Putrayasa, I. B. (2019). Peningkatan Kemampuan Siswa Menulis Teks Negosiasi Dengan Menggunakan Metode Karyawisata Kelas X Ipa 1 Man 1 Buleleng. Jurnal Pendidikan Bahasa dan Sastra Indonesia Undiksha, 8(2). doi:10.23887/jjpbs.v8i2.20615

[6] Huda, A. I. N., Turahmat, T., \& Azizah, A. (2018). Peningkatan Kemampuan Menulis Teks Negosiasi dengan Model Pembelajaran Group Investigation pada Siswa Kelas X SMA Negeri 2 Rembang. Jurnal Pendidikan Bahasa Indonesia, 5(2), 19. doi:10.30659/j.v5i2.2349

[7] Leung, C. (2007). Dynamic Assessment: Assessment for and as teaching? Language Assessment Quarterly, 4(3), 257-278.

[8] Mantra, IBN., Widiastuti, IAMS. (2019). An Analysis of EFL Students' Writing ability to Enhance Their Micro and Macro Writing Skill. International Journal of Linguistics and Discourse Analytics, 1(1), 29-34

[9] Tzuriel, D. (2011). Revealing the effects of cognitive education programs through Dynamic Assessment, Assessment in Education: Principles, Policy \& Practice (Vol. 18, pp. 113-131).

[10] Widiastuti, I. A. M. S., Mukminatien, N., Prayogo, J. A., \& Irawati, E. (2019). Students' Perception of Assessment and Feedback Practices: Making Learning Visible. International Journal of Sustainability, Education, and Global Creative Economy (IJSEGCE), 2(1), 1-8. https://doi.org/https://doi.org/10.1234/ijsegce.v2i1.49

[11] Widiastuti, I. A. M. S., Mukminatien, N., Prayogo, J. A., \& Irawati, E. (2020). Dissonances between Teachers' Beliefs and Practices of Formative Assessment in EFL Classes. International Journal of Instruction (IJI), 13(1), 71-84. https://doi.org/https://doi.org/10.29333/iji.2020.1315a

[12] Wirastuti, IGAP., Mantra. (2019). Implementation Ofpicture Sequence Tasktoassessthenarrativeparagraph Writingabilityof The first Semester of Law Faculty. International Journal of Applied Science and Sustainable Development (IJASSD), 1(1), 23-28

[13] Widiastuti, I. A. M. S., \& Saukah, A. (2017). Formative assessment in efl classroom practices. Bahasa dan Seni: Jurnal Bahasa, Sastra, Seni, dan Pengajarannya, 45(1), 5063. http://journal2.um.ac.id/index.php/jbs/article/view/677/419 